\title{
"It Is Better to Be a Refugee Than a Turkana in Kakuma": Revisiting the Relationship between Hosts and Refugees in Kenya
}

\author{
Ekuru Aukot
}

\begin{abstract}
The article echoes stories and perceptions of the hosts to the refugees in their day-to-day relations in Kakuma refugee camp with little emphasis on academic abstraction of refugee protection contained in international instruments but rather on the realities on the ground. It is argued that good refugee host relations enhance refugees' enjoyment of their rights under the international conventions and promote local integration. The article discusses areas of conflict between refugees and their hosts and how these factors endanger refugees' physical protection, and it echoes the hosts' solutions to the conflicts. The failure of local integration is attributed to poor refugee host relations. Consequently, it is argued that even the enactment of refugeespecific legislation "that would give force" to the international conventions will not necessarily improve refugees' enjoyment of their rights as long as, through a practice of selective compassion by humanitarian agencies and international refugee law, refugees are targeted for assistance without regard to the negative impact on the local economy and its residents.
\end{abstract}

\section{Résumé}

Cet article rapporte des récits et des perceptions émanant des hôtes vis-à-vis des réfu giés dans leurs relations quotidiennes dans le camp de réfugiés de Kakuma. II fait peu de cas des dispositions théoriques en matière de protection de réfugiés contenues dans les instruments internationaux, mais considère plutôt la réalité sur le terrain.
Il fait valoir que de bonnes relations entre réfugiés et hôtes augmentent la capacité des réfugiés de se prévaloir des droits que leur confèrent les conventions internationales et facilitent l'intégration au niveau local. L'article examine les zones de conflit entre réfugiés et hôtes et aussi comment ces facteurs constituent un danger à la protection physique des réfugiés. II relate aussi les solutions que les hôtes proposent à ces conflits. L'échec del'intégration locale est attribuéaux mauvaises relations entre réfugiés et hôtes. Par conséquent, I'article soutient que même la promulgation d'une loi rendant exécutoire les conventions internationales sur les réfugiés ne permettra pas nécessairement à ces derniers de mieux jouir de leurs droits. Selon l'article, ce phénomène durera tant queles agences humanitaires et le droit international des réfugiés pratiquent une « compassion sélective», ciblant les réfugiés pour les assister, mais sans tenir compte de l'impact négatif que cela peut avoir sur l'économie locale et ses habitants.

It is better to be a refugee than a Turkana in Kakuma. ${ }^{1}$

\section{Introduction}

B etween 1991 and 1998, the civil wars in the H orn and the Great Lakes region of Africa brought ten nationalities to live among a people in Turkana District, Kenya, so impoverished that the refugees came to be seen as a threat. The region experienced an unprecedented wave of refugee flows, resulting in large concentrations not only of refugees, but also of hundreds of thousands of displaced 
peasants, agro-pastoralists, urban dwellers, and militias. This escalated in the 1999-2001 civil and political unrest in the DRC and Sudan, the recent election violence in the islands of Pemba and Zanzibar, ${ }^{2}$ and the continued insurgence in northern Ugandan by the Lord Resistance Army (LRA). The flight of these people poses problems that have far-reaching consequences for the host country, the region, and individuals.

This article focuses on the exiles' reception in Kakuma refugee camp, not by UNHCR or the government, but by the local tribe, the Turkana (hereinafter, the hosts). In the first part, it briefly introduces Kakuma, the hosts, and the refugees. Secondly, the areas of conflict are discussed. Thirdly, and in view of the context, it poses the question whether local integration as a durable solution could be realized. Fourthly, the possible impact of refugee-specific legislation, if any, is analyzed. In conclusion, the future of Kakuma refugee camp in its protracted state is contemplated.

The article relies on fieldwork observations; formal and informal meetings with the hosts, refugees, and NGOs; situational reports and the hosts' correspondence to UNHCR and her Implementing partners (IPS); and their local MP, as well as personal experience. The discourse adopts narratives from the hosts' perspective, through which they raise challenging questions to the international principle of refugee protection, and their views render Kenya as the receiving state unpopular among its people. ${ }^{3}$ The time frame for the observation is slightly over two years, including input from two recent three-month field visits, as part of a doctoral thesis. ${ }^{4}$

\section{The Kakuma Refugee Camp, the H osts, and the Refugees}

Kakuma refugee camp is located in Turkana district, one of the remotest parts of Kenya. The temperatureaverages $40^{\circ} \mathrm{C}$. "N othing" grows agriculturally in Kakuma. The area and its residents are afflicted by famines, droughts, and severe economic setbacks, making it impossible for them to eke out a minimum living.

The camp was established in 1992 owing to the plight of about 30,000 to 40,000 Sudanese "walking boys" or "lost boys" who were forcefully returned to Sudan when the Ethiopian regime of Mengistu was toppled in 1991. The "boys" walked in the wilderness and wandered into Kenya. ${ }^{5}$ The camp has urban refugees from Burundi, Rwanda, and Ethiopia as well as pastoralist refugees of Sudanese, Somali, Ugandan, and Ethiopian origin.

The high refugee population forced the Government of Kenya (GoK) to adopt the encampment policy, which brought together approximately 60,000 Sudanese with about 7,000 Ethiopians and Eritreans (with the recent
Ethiopia-Eritrea political instability, their numbers have increased). Rwandans and Burundians are about 300 with the majority living in the urban areas of $\mathrm{N}$ airobi. There are 295 U gandans and 243 Congolese. ${ }^{6}$ The Somali, including the Somali-Bantu, are about 10,000 with an increase since the closure of the Mombasa camps, forcing UNHCR to relocate most refugees to Kakuma, ${ }^{7}$ and theinsecurity in the Dadaab camps. ${ }^{8}$ The increase necessitated the creation of Kakuma II and III to accommodate the newcomers and those who passed status determination interviews in $\mathrm{N}$ airobi, as well as new arrivals from Sudan, Ethiopia, and Eritrea. The exact population of refugees in Kenya is unknown. UNHCR gives a figure of those living in the camp only and an estimate of about 100,000 living in the urban centres in Kenya.

The hosts are nomadic pastoralists who depend on cattle for their survival. They areamong the 43 per cent of Kenya's population that live in absolute poverty and their basic needs have remained unmet for decades. They, inter alia, depend on missionary aid for education and health. In Kakuma, one notices the almost complete absence of the GoK save for the police post, which was constructed by the UNHCR to protect refugees from alleged hostilities of their hosts, and the District Officer (DO) who mainly signstravel documents (TDs) for refugees temporarily leaving the camp.

Turkana district is evidently marginalized in developmental terms. Its inhabitants are an ethnic minority who are under-represented politically with limited economic resources. They are debilitated by diseases, and for a long time have been displaced through conflicts with their neighbours, the Pokot, Karamojong, etc. It is among these people that the GoK has created the oldest refugee camp with UNHCR administering humanitarian assistance among the refugees. The camp provides a locality for growing social conflict, economic decline, and political abuse, which has often frustrated the refugee protection ideal. The impact of refugees in Kakuma cannot therefore be underestimated. It has culminated in the hosts' grievances, which are motivated by unequal treatment by both the national and international regime of refugee protection. Their demands raise fundamental and conceptual issues, which question the tenets of humanitarianism and equality in human rights protection.

In contrast refugees receive free services including shelter, food, firewood, and health care, which have created a social, economic, and psychological imbalance. The population of over 83,000 refugees is pitted against 10,000 local hosts. As beneficiaries of humanitarian assistance, refugees are better off than their hosts. The problems faced by the hosts are similar to those that caused the flight of refugees. 
The hosts mirror the problems common between them and refugees. Yet the hosts cannot ben fit from refugee aid due to the intricacies of refugee law that someone must be outside his country of origin and without the protection of that state. ${ }^{9}$ This has led to the criticism that "international aid can offer nothing better than the bleakness of the settlements and camps while the generosity of the poor in host countries can do no more than share their poverty." ${ }^{\prime 10}$ It would thus appear self-defeating to "better" refugees' lives in an environment afflicted by the same problems that forced them to leave their countries.

The commonality of problems between refugees and hosts raises doubts whether the refugee in Kakuma is the one described in the conventions ${ }^{11}$ with the expanded definition in article 1 (2) of the OAU Convention that applies the term "refugee"

...to every person who owing to external aggression, occupation, foreign domination or events seriously disturbing public order in either part or thewhole of his country of origin or nationality is compelled to leave his place of habitual residence in order to seek refuge...

The term "refugee" has therefore become a term of art "with a content verifiable according to principles of general international law." 12 The definition becomes problematic due to circumstances that exist in Kakuma. The hosts' history of displacement meets the expanded UN HCR mandate for Internally Displaced Persons (IDPs). It is arguable that the hosts could meet the criteria of refugees under the OAU Convention and any attempt at selective protection defeats the principles of human rights protection.

International refugee law as a concept is limited, which explains why "economic refugees" are not considered. ${ }^{13}$ Due to the dilemma presented by economic refugees, States haveinsisted on restrictivecriteria for identifying thosewho benefit from refugee protection. However, in Kenya most refugees - Somalis, Sudanese, and Congolese - are recognized prima facie, which casts doubt on their statuses. In fact 99 per cent of refugees in Kakuma have not undergone refugee status determination procedures (RSD). This situation is engendered by the presence of victims of natural calamities and generalized violence.

Subsequently, refugee influx in Kakuma gives rise to problems of a complex nature. The refugee is concerned with personal survival and exploitation of available opportunities including those offered by the UNHCR. For the world community, the problem, if recognized at all, is perceived as a humanitarian issue to be forgotten as soon as the pressing needs are partially satisfied. For thehosts, on the other hand, it creates a complex series of problems, including severe pressure on social services and infrastructure.

The hosts find themselves in contact with foreigners who fled their countries because of wars, poor economic situations, political persecution, and marginalization. The intervention by UNHCR and GoK on behalf of refugees cannot possibly be comprehended by the hosts because of their own expectations; hence their many accusations, which threaten refugee protection. In the hosts' minds linger the questions, why and how are refugees different from them? Are the GoK and theinternational community being selectively compassionate in humanitarian assistance? Doesn't that compromise humanitarian principles?

\section{The Factors Affecting Refugee-H ost Relations}

The refugee-host relation remains a stumbling block. These realities challenge the UN HCR's mandate in providing "international protection" and in seeking permanent solutions to refugee problems. Humanitarian aid was exclusively channeled to the refugees without regard to their hosts in spite of the Daily Nation's 1999-2000 wide report on the Turkana famine that killed many. Refugee aid is not seen as humanitarian but rather constructed as an economic gain that guarantees life.

The imbalance is clearly pronounced when refugees receive humanitarian assistance, which enables them to supplement their "incomes." This has resulted in scapegoating, which has often portrayed refugees as sources of political, economic, social, and cultural problems. ${ }^{14}$ Refugees are blamed for burdening an almost non-existent economy, e.g., through local shopkeepers who complain that their prices are regulated and taxed. In a letter to UNHCR, they wanted refugees to leave the Kakuma area. H owever, after they left, the hosts followed them to the camp because of lower food prices, leading to a booming business in the camp.

The hosts' anxiety towards the refugees can be posed in terms of a series of questions: Why do some people flee while others who are in similar situations choose to stay? What makes "aliens" special compared to other nationals who opt not to flee despite facing the same circumstances? This led to complaints attributed to the refugees' presence with specific complaints against UNHCR, IPs including other NGOs, and the GoK. These factors were not complained of before refugees arrived. Whereas there has been a substantial administrative and infrastructural improvement in the area owing to the refugees' presence, the hosts' summarily allege that since 1992 they have...

[e]xperienced problems caused by their habitation of our land and which none of the previous UN H CR sub-office heads have 
bothered to address... we have observed that, the Turkana have turned to be more poorer than the refugees. ${ }^{15}$

\subsection{Insecurity, Crimes, and Refugee to-R efugee Conflict} When the camp was established, the Turkana and the refugees enjoyed good relations, which the Turkana say declined later due to provocation by the Dinka refugees who were "roaming around the villages without serious business," stealing, and causing un provoked fights with the Turkana. ${ }^{16}$ Realizing that their hosts did not want the cutting of trees, the Dinka formed groups that became a security threat, which continued "massive felling of trees by well armed gangs," and are also accused of repeatedly raping Turkana women. ${ }^{17}$ The murder of "innocent Turkana" topped thelist and on the same note the Turkana alleged that Dinkas threatened to kill them before returning to Sudan. ${ }^{18}$ Turkana elders revealed fears of "new" crimes, e.g., robbery with violence, which have resulted in the increase of firearms that was blamed on the Sudanese, Ethiopians, and U gandans who are close to their borders.

The hosts argued that criminals of Turkana origin now collaborated with those of refugee origin. In distinguishing theft of animals from traditional cattle rustling, the latter, the hosts argue, guaranteed peaceful settlement because whenever the cattle were identified, the "thief'" handed them over to the bona fide owner. The situation has changed, because the Ethiopian and Somali butchery owners buy animals from the "owner" who is a Turkana, but when another Turkana clai ms the animal that truly belongs to him, conflict always ensues.

On the other hand, refugees argue that the practice of cattle rustling by the Turkana is criminal, and that the authorities have left it unpunished. The example is given of a refugee who buys a cow from a Turkana, who will then come in the night to "take it away," on the pretext of "cattle-rustling." To solve this problem, refugees are advised not to keep cattle, and asked to buy one only when they want to slaughter it. A security committee chaired by the DO was proposed and it became the Kakuma Elders Consultative Committee, which was to oversee refugeehost relations and to report any offenders to the Kenya police. Alternatively, they proposed that UNHCR should repatriate all the Dinka refugees.

The hosts perceive refugee-to-refugee conflict as painting a bad image. Their violence in the camp goes unpunished, ${ }^{19}$ hence impunity is perceived as affecting relationships because constant fights among the refugees sometimes result in deaths. Since refugees disrupt the tranquility of the hosts' environment, they are seen as a security threat. Their political affiliation has characterized refugees' internal social relations with conflicts, which has bearings on refugees' adjustment and integration in Kakuma. For instance, the Dinka ethnic tribes, the Bor and the Bahrelgazal, always fight. Yet the two gang up against the Nuer tribe. This conflict al ways reflected the political situation in Sudan that arises from the support of either John Garang or Riak Macher of the Sudanese People's Liberation Army (SPLA). On the other hand the Luo, a minority group, are considered "outsiders" in theSudanesecommunity because their political stand over the war in the Sudan is not clear.

Clanism among the Somali community is a source of violence because some clans claim superiority over others. The Somali-Bantu are segregated because of the stigma that they were once "slaves" in Somalia. The Hutu and Tutsis, the O romo and the Ethiopian always suspect each other of espionage, escalating their old hatred. According to Rwandans, the real identity of each member is uncertain, i.e. whether Hutu from Burundi or Rwanda and vice versa. Generally, the Dinka are accused of claiming the ownership of Kakuma refugee camp, and the chairman of theSudanese community of claiming to be the overall chairman of all other refugees; and the hosts perceive insubordination from both the refugees and the refugee agencies, which do not see them as having a say in matters affecting their area. The above situation has sparked hostilities, prompting the hosts to brand the refugees "killers." To the hosts and other refugees, some elements, especially the SPLA supporters among the Dinka tribe, say that Kakuma is but a resting and recuperating place, portraying them as peoplenot deserving protection.

\subsection{Water and Food Security}

The population of Kakuma was small when water facilities were constructed but shot up drastically when refugees settled. The water lines were then overloaded because the generator pumping water was too small, whiletheonly windmill broke down, resulting in water shortage. This has resulted in strict regulation of the supply, because of which conflicts have ensued at the water collection points. The hosts argue that their women are forced to travel long distances to fetch water resulting in "chest pains and miscarriages." The hosts suggested that the existing windmill be repaired or a new one be installed and a new solar-powered system be erected, and that all boreholes be repaired and the old generator be replaced with a powerful one.

Food insecurity is also blamed on refugees. As nomadic pastoralists, the hosts who, together with their cattle, depend on pasture and water for survival claim that in settled areas likeKakuma, Kalobeyei, Letea, and Lopur theland has al ready been destroyed by soil erosion caused by the presence of refugees. UNH CR was asked to dig four water dams in Kakuma Division in areas with adequate grass but no 
water, so that the livestock can get water. Also, UNHCR was asked to provide materials or technical assistance to curb erosion.

\subsection{Employment and Refugee Agencies' Attitudes towards Hosts}

Theattitude of someN GOs combined with the hosts' outcry over bias in employment is a setback to refugee protection in Kakuma. The hosts argue that their land has lost the natural capacity to sustain their means of livelihood because of occupation and devastation by refugees, causing acrimony and agitation among theyouth, ${ }^{20}$ resulting in Turkana Environmental Resource Association (TERA) and Kakuma Integrated Development Organization (KIDO), etc.

Employers all egedly favour "outsiders." The hosts argue that it is because all NGO sare headed by non-Turkana who practice nepotism, tribalism, and favouritism, and sideline them because of a stereotype that they are "primitive" and unqualified. This thought seems to have been erroneously borrowed by some commentators who ignorehow relevant the issue is in refugee protection, and instead write that:

Although 85 percent of jobsin thecamp aresupposedly reserved for thelocal people, few of theTurkana are sufficiently qualified for the better-paid posts. Those who do have the necessary qualifications also tend to be highly politicized, something, which has contributed to regular disputes over issues such as recruitment, dismissals and promotions. ${ }^{21}$

With due respect to this view it is questionablewhy some agencies prefer employees from a particular tribe. Thehosts perceiveit as tribalism, a factor that predominates in almost all aspects of relations among the forty-seven ethnicities in Kenya. In fact the hosts contend that the few Turkana who are employed have always been dismissed without reason even with a contract of employment in force. Whenever the responsible officers are confronted over thisissuethey shift the blame to authorities in N airobi. The hosts reveal that even the subordinate staff employed at the camp are relatives of senior officers. They simply ask: doesonereally need a certificate qualification to sweep a compound or clean a toilet?

The attitude of some IPs as well as that of UNHCR has contributed adversely to the resentment of refugees by the hosts. For example the International Rescue Committee (IRC) was accused of "overtly abusing and offending the local community in ways that left it with no alternative except its exit from Kakuma within the shortest time possible." 22 In defense the NGOs stated that "as international staff they are above local politics," but they were reminded that if it were not for the refugees, they would not be in
Kakuma, and that "anybody abovelocal politics on our soil should operate in the air." ${ }^{23}$ Whereas it is understandable that NGOs cannot participate in "local politics," this does not warrant disrespect and ignoring complaints that would affect refugee protection.

A list of IRC employees as at M arch 1998 showed that out of forty-nine employees, only ten were from the host community. Referring to this situation, the hosts say that majority of its staff are "air-lifted from Nairobi in the U N HCR plane." When the Lutheran World Federation (LWF) handed over the management of the Kakuma hospital to IRC, staff from the host community were summarily dismissed. Those who wanted their contracts renewed were, as a precondition, forced to test for HIV/AIDS.

The NGOs were also accused of "racism" and being insensitive to cultural values. The utterances of the heads of IRC were described as being "heavily laden with racial overtones typical of Ku Klux Klan ideology." 24 The hatred of NGOs, in spite of being well documented, has not been addressed, yet on the receiving end is the refugee, who unknowingly mixes with the angry hosts.

The hosts requested that NGOs operating in Kakuma give them priority in positions they are qualified in - listed as co-ordinators, administrators, supervisors, etc. Secondly, jobs must be advertised and recruited in Kakuma because they lack the resources to travel to and stay in Nairobi. Thirdly, the practice of volunteer staff prior to actual employment should be abolished because it arguably contravenes accountability of funds of the organization, as people worked as "volunteers" when they were actually entitled to a salary. Lastly, all subordinate posts - watchmen, cleaners, loaders, etc. - must "automatically be granted to the locals."

\subsection{Supply Tenders}

The hosts perceive the camp situation as presenting an opportunity for the exploitation of the local economy. In 1992, the hosts supplied available commodities such as firewood, makuti (thatch) for building, and meat. This changed later with theintroduction of competitivetendering and the emergence of numerous non-existent groups, belonging to non-Turkana and some "senior people." This marked TERA's advocacy in favour of the hosts; the hosts were denied a contract worth 32 million Kenya shillings for the supply of firewood to the refugees. ${ }^{25}$

Therefore the exploitation of readily available local resources became contentious because thatching materials highly needed by the refugees, which are found at Kalobeyei, 27 kilometers from Kakuma were now allegedly "imported." In response the tendering authorities argued that the Turkana cannot deliver according to the terms of 
the tender and that is why suppliers were contracted from Kitale, about 600 kilometers from the camp.

The hosts suggested that the criteria for tendering, especially for makuti and meat, beclearly defined, and that their local leaders like the chiefs be co-opted into the tendering committee to avoid bias and "ghost groups." Lastly, the Turkana, being pastoralists, should be allowed and encouraged to supply meat and milk products since they have plenty of livestock. It is logical to purchase poultry and bacon products from elsewhere because they are not available in Kakuma.

\subsection{D eforestation}

Not only has deforestation catalyzed the refugee-host conflict, it has equally demeaned the respected " $N$ yayo philosophy" of soil conservation, which is popularized in the rural areas with the slogan "cut one, plant two." The refugees cut many and replace none. In Kenya the Chiefs and the DOs at thelower levels and the District Commissioners (DCs) at the higher levels portray that slogan of environmental conservation as a presidential law, which it is an offence to disobey. Government agents have in the past held weekly barazas (meetings) on the impact of deforestation, but with the refugees, they havebecomealoof and the hosts feel discriminated against in favour of the refugees.

The hosts are alarmed at the rate at which refugees cause deforestation, as evidenced in Zone 7 of thecamp, inhabited by the Sudanese community. The hosts say that the refugees, when confronted, become violent and continue with massive destruction of local tree species for cooking and construction. Hence there are daily fights between the two communities. Refugees are accused of destroying trees at distances of up to 5 kilometers. The hosts argue that their livestock largely depend on these trees, and deforestation has exposed the topsoil to wind and water erosion. On the other hand the hosts want to control the supply of firewood and building materials as an economic gain, which is disrupted by the refugees.

The hosts asked UNHCR to do two things: firstly, to confine refugees to the camp and to provide them with cooking and building materials; and secondly, to initiate mass planting of trees, especially the local species, and to employ some refugees as forest guards to avoid conflict.

\subsection{Education}

Since 1992, primary schools in the camp have increased to twenty in number with five secondary schools. Comparing to the period before the refugees' arrival, the hosts construe this increase to mean that the government favours the refugees, with at least 20,000 refugee children attending school. It is difficult for the hosts' children to be admitted to the schools in the camp, yet refugee children are admitted in large numbers to schools run by the hosts, e.g., Lopur Primary School. This has arisen due to the questionablequality of education in the camps and further because refugees, particularly Somali and Sudanese, prefer the Kenyan education system. In effect local schools lack facilities to accommodate the increase. Hence the hosts required UNHCR to fence and provide water to the local schools as well as to renovate classrooms, desks, and where necessary to provide food, including establishing nutritional feeding centres. It was again noted that the schools needed textbooks, chalk, and pressure lamps for study. It was also suggested "preschool activities at village level be initiated."

\subsection{Health}

Although the hosts appreciate the health facilities extended to them, they contend that poor sanitation in Kakuma is due to lack of toilet facilities and the many refugees, which led to bad sanitary conditions and the trading in commodities whose suitability for human consumption was "highly suspect." The recent arrivals, Somali-Bantu, have been accused of using the local wells on the river Tarach as "bathtubs," which has resulted in water-borne diseases such as typhoid, bilharzia, and dysentery.

The Sudanese minors are accused of using the bed of the river as a football pitch and a venue for "other social adventures" and their prolonged presence in the riverbed results in "pollution." However, part of the blame is attributed to the authorities concerned because they did not conduct impact analysis to determine the extent to which the activities of the refugees would bring menace to their hosts and the environment. The construction of latrines was suggested as a solution.

\subsection{Cultural Erosion}

In traditional Turkana, the sanctity of marriage was and still is a treasured value. A bride could collect in dowry at least thirty animals. $M$ arriages were planned and celebrated in a tradition that involved the two families. In violation of that tradition there is an increasing untraditional elopement of Turkana girls with refugees. Although elopement is not an "alien" practice in Turkana, the expectation was that, once the family of the girl "reclaimed" her, they would beaccorded due respect and negotiations for marriage would begin. This is because often elopements initiated marriage proceedings. Secondly, it demonstrated the groom's intention to marry, which was to spark a process of initiation and responsibility in society. But refugees do not understand the above practice and its importance to the Turkana who traditionally demanded dowry or pregnancy compensation. Refugees often object on the grounds that they do not have the cows de- 
manded or they do not relate to the culture, and a dismissive argument often has been that it isthegirlswho follow of their own volition.

The elders confirmed the existence of another factor causing girls to breach those traditional values: the duty to fend for their impoverished families through those "marriages." Eldersal so blamed refugees for thegrowth of brothels and prostitution, resulting in venereal disease, which the community argues is new. ${ }^{26}$

\subsection{Local v. National Politics}

What emerged shortly after refugees settled were boreholes, schools, hospitals, apolicestation, and freefood for refugees. The question then arose as to whether the refugees were taking over their land. This was followed by popular agitation to oust the ruling party's M P, as the hosts had lost faith in the government, and in the 1997 general elections an opposition candidate won. $\mathrm{H}$ is triumph engendered a call for the immediate departure of refugees from Kakuma.

Forty years after independence, the hosts are, because of refugees, asking the government to give them basic rights, inter alia, education, health, and employment. ${ }^{27}$ They express hatred of the government for generally sidelining them in development. The political history has contributed to the hosts' problems, but the refugees' presence has exposed the gravity of their political marginalization. In a letter, the hosts were grateful to the new M P for rescuing them from "bondage of intimidation, oppression, depression, abuses, harassment and insubordination." 28 The MP was asked to influence the employment of the hosts in both the government and the NGO sector, to promote education, and to influence the development of infrastructure.

The hosts' resentment of the government was highlighted during the creation of Kakuma II. The negotiation involved the government and UNHCR officials excluding the villagers. This elicited problems from two fronts. From the legal perspective, Turkana District is designated as falling under customary law, and therefore the taking away of that land without consulting the owners was unconstitutional. ${ }^{29}$ Secondly, the extension of this camp sparked disagreement because the Turkana living in that area were pushed further away from services already delivered in Kakuma. This was seen as an act further marginalizing them. The elders were intimidated and asked to obey the government's order because, it was argued, as a signatory to international refugeelaw, Kenya wasunder an obligation to host refugees. The elders further alleged that bribery was used to influence some members of the committee. ${ }^{30}$

A proposal for compensation was suggested where the twenty-six affected families of 477 people be provided donkeys as means of migrating to other areas. Since these families kept goats in the area, movement into more harsh areas required the type of animals that could resist the new environment. Hence they demanded camels and UN HCR was asked to construct livestock watering holes at Lobokat and Pelekech areas. Also they asked that the borehole at Zone 7 of the camp be exclusively used by the hosts.

\section{Is Local Integration Possible?}

The short answer to this question is "no" because the above factors inhibit its realization. The areas of conflict are inherent in the following factors: First, the socio-cultural set-up lacks the capacity to absorb the refugees. It rejects and segregates them because refugees cannot participate in the dominant culture of the hosts including their inability to speak the local language. This is engendered by the hosts' perceptions, the educational and occupational backgrounds of the refugees and hosts, which are variables that determine the speed, the direction, and the level of integration. But these aspects are in conflict in Kakuma.

Secondly, refugees in Kakuma, like their hosts, are vulnerable to marginalization. ${ }^{31}$ Economically, they are both inhibited from participating in the productive system, denying individuals the use of "his ideas, histalents, his hopes upon the community that has admitted him." ${ }^{32}$ They would only achieve integration when as migrants they

... becomeaworkingpart of their adopted Society, takeon many of its attitudes and behaviour patterns and participate freely in its activities, but at the same time retain a measure of their original cultural identity and ethnicity. ${ }^{33}$

But employment, which is usually a first step towards meaningful integration, is unavailable. The employment of international and national staff in almost all areas creates an unemployed population that continues to depend on humanitarian aid.

Thirdly, refugees cannot participate in the political life of their hosts..$^{34}$ The practicein Kakuma, as you will often hear, is that refugees shall not participatein the politics of the host community, and shall not even question the attitude of government agents towards them. The refugees may not demonstrate even against their own embassies, because that is considered "political" with respect to the host government in spite of evidence that countries of origin interfere with their asylum. ${ }^{35}$

Fourthly, the GoK's encampment policy inhibits integration. Through numerous police roadblocks along the KitaleLodwar-Kakuma-Lokichoggio roads, it restricts refugee movement, giving rise to a chronic culture of corruption, with refugees buying their way out of the camp. In Nairobi refugees must carry identification documents all the time, 
which the police do not respect, hence the contradiction that:

While unfailingly generous in giving asylum and relief to rural refugees, ... African Governments have been slow in promoting real integration and slower with regard to naturalization. The stringent security regulations in force ... in rural settlements have also served to curtail integration. ${ }^{36}$

Lastly, the psychological state of the refugees also delays integration because of self-denial for years that their exile may be long or even permanent. The refugees "instead ... believe that their exile is temporary and that ... a radical change... will upset the status quo and enable them to re turn home." 37 The refugees in Kakuma are very disillusioned that there will be an end to their exile, because just when the situation seemed favourablefor repatriation, conflicts al ways broke out such as the Eritrea-Ethiopia conflict of 1998-999, the DRC-U ganda-Rwanda war, the collapse of theSudan peacetalks, and the R wandan refugees' belief that genocide is still taking place.

The quest for integration in Kakuma is a process that went through several stages, which are ideally peaceful, exploratory, or even ignorant but later become competitive and conflictual over scarce resources, with the end-game being assimilation, integration, or segregation.38 However, Kakuma mirrors a situation where neither integration nor assimilation seems possible. Furthermore, African societies are multi-ethnic and the recognition of heterogeneity rather than assimilation of one group by another is the modusvivendi, i.e., "liveand let live" based on tolerance of differences, solidarity, and positiveintegration. In Kakuma, integration would mean a situation wherehosts and refugees coexist and share the same resources without conflict. $^{39}$

Integration, it has been suggested, must take into account causes of refugees' maladjustment because flight "desocializes" theindividual when it uproots him. Social integration is, however, not only determined by host-society factors but also by the socio-cultural backgrounds of the exiles. ${ }^{40}$ In Kakuma refugee life is marred by disruption and abandonment of life goals, marriage is delayed; education is discontinued and careers are given up. To that extent integration becomesidealistic and in Kakuma can besummarized as a failed policy. The situation is itself a "push-factor" for repatriation. This difficulty therefore solicits for solutions towards the refugee hosts peaceful coexistence. One suggestion would be the contribution of law with the hope that the society where refugees live would respect the rule of law and in its presence, it would protect refugees' endeavour to integrate.

\section{Domestic Legislation an Exercise in Futility?}

Kenya acceded to the 1951 Convention relating to the Status of Refugees (the 1951 Convention), its Protocol, and the OAU Convention in 1963, 1982, and 1992 respectively. Kenya also acceded to other human rights treaties including the 1948 Universal Declaration of H uman Rights (UDHR), accepting therefore to protect refugees. The legal definition of a refugee in Kenya derives from these treaties. H owever, pursuant to a dualist approach to international law, the treaties have no direct effect in Kenya because they have not been incorporated into the legal framework through an Act of Parliament, without which refugees are presently at the mercy of ad hoc policies.

Incorporation of treaties into Kenyan law would arguably define the eligibility procedure and the authority re sponsible for granting asylum, check against detention, police "swoops" and forceful repatriation as an existing danger. Some refugees who are disillusioned by international law aremore concerned by the absence of Kenyan law for their protection. Without legislation, refugees are vulnerable to abuse, their rights are violated by both the authorities and their hosts, and they are used as scapegoats for the GoK's failures to the hosts. ${ }^{41}$ The current 2001 Refugee Draft Bill has considered this view. But it is not clear how this law, if enacted, would reduce the refugeeshoststension. The earlier bills of 1991, 1994, 1998, and 1999 were never tabled in Parliament although the current $\mathrm{M}$ inister promises to table the current one. ${ }^{42}$

To enhance good relations with the hosts, UNHCR it seems has no choice but to redefine the refugee in Kakuma. UNHCR could seriously consider the hosts as other groups of persons who can be or presumed to be without or unable to avail themselves of the protection of their government (often called "displaced persons" or "persons of concern")..$^{43}$ By including the hosts in its assistance, UNHCR would be complying with her humanitarian character; otherwise Kenya'senactment of a law to protect refugees would be perceived as preference over her own people. After all, as ID Ps the hosts haveno legal protection apart from mereUN guidelines. ${ }^{44}$

However, refugees left their countries for reasons that include, inter alia, the fear of anticipated danger, persecution, political opposition, forced labour, and economic problems. Although the hosts experience some of these problems, the difference is that the refugee has crossed an international border to warrant assistance. Perhaps the re luctance by the Turkana to flee to neighbouring countries is in itself a solution to the root causes of forced migration, and the GoK should today grasp the challenge to address the issue of insecurity and that of IDPs that predominates in northwestern Kenya. These entire issues amount to the 
protection of human rights, so that the enactment of refugee legislation will do very little, if anything at all, to better refugee lives in the locality.

\section{Conclusion}

The importance of rethinking a modality for the implementation of humanitarian assistance where refugees reside is emphasized. ${ }^{45}$ The UNHCR and the GoK have ignored the importance of good refugee-host relations. The areas of conflict demonstrate the hosts' desire to be involved in hosting refugees. Kakuma exposes the weaknesses of the present refugee regime, especially the internal problems of the host government vis-à-vis its nationals. Due to refugee aid, the hosts resent their government because the refugees offer them ayardstick. The hosts may arguably bewrong but these are the realities that refugees face daily and not the beauty of the Conventions. In fact whatever measures the international community takes, one of them would be to convince the hosts why refugees appear privileged in their midst. It is debatable that the hosts' claims may be unreasonable but these issues challenge our daily protection of refugees especially in Africa. The hosts' perceptions are in fact not any different from xenophobic and racial attitudes in Western countries.

In particular, the following issues are emphasized: Firstly, I have generally questioned the implications of protracted refugee camps and how they result in more problemsfor refugees. Perhaps the abolition of the camps would ameliorater refugee suffering. Kakuma has proved that camp policy is bad for various reasons. First, it directly violates the fundamental freedoms of movement, among other rights. Second, it discourages local integration, as refugees are caged in the camps, which are inhabitable (in their protracted state), yet the hosts are expected by the government to live in Kakuma harmoniously with the refugees. ${ }^{46}$ Third, it encourages corruption, as refugees will al ways buy their way out of the camp when there is need to travel. Therefore whether refugees in Kakuma are better off than their hosts depends on the perception of the refugee problem as being more than just flight of people across borders, because a solution of their problem involves allocation of scarce resources and services in the host environment. Hence what makes life bearable in Kakuma is interpreted as a common resource.

Secondly, the creation of camps among impoverished and underdeveloped hosts challenges the application of humanitarian aid and is entirely a problem of the government that has discouraged peaceful coexistence as refugees are "advantaged" over the hosts. The latter's grievances rest in the government's failure to develop their region. Demand for compensation should therefore be directed at the government and not the international community. Paradoxically it appears that unless assistance considers the needs of the poor hosts and contributes towards their development, there is al ways the danger that refugees will be blamed for the hosts' problems. However, the hosts do not care who the aid is for, because they too exist in the same condition as the refugees, and naturally deserve assistance, which if they are denied makes the refugees' status better than that of the host. Kakuma refugee camp therefore presents a dilemma where the hosts do menial jobs for the refugees; they arehousehel ps, "dishwashers," and baby-sitters for refugee children. The hosts therefore depend on the refugees' presence, and this makes them vulnerable to abuse, especially when hunger bites. ${ }^{47}$

Thirdly, it is shown that the hosts "grab" theopportunity to blame refugees and more specifically use the areas of conflict as "scapegoating" tools. Ignorance also plays a major role because the allegation and the hosts' proposed solutions sound rather naïve but the real danger is that the protection ideal is far from realization. Governments have an obligation to popularize the hosting of refugees among their nationals. However, it is right to say that both objective and subjective reasons influence the refugee host conflicts.

Fourthly, Kakuma is not conducive for the realization of local integration, which is generally very low in Kenya. To promote integration, refugee assistance should be planned on "refugee affected areas" rather than establishing parallel services in camps. ${ }^{48}$ The GoK should adopt a policy which uses the available resources for the sustainability of both refugees and their hosts. Assistance policies have encouraged the confinement of refugees in the camps, rendering them dependent on relief. ${ }^{49} \mathrm{H}$ ence the would-be host governments want the guarantee of refugee aid before admitting refugees. ${ }^{50}$ This image has portrayed the refugee as a "problem" rather than as persons with problems, and as such has obscured thereality that refugees arepersonsready to put their energies into productivework that could ben efit their hosts.

Alternatively, the GoK could adopt the two-tier approach, proposed by the Centre for Development and Enterprise (CDE) in South Africa where free movement of skilled people from anywhere in the world is admitted, and secondly, theprobationary entry of unskilled peoplewho, once they have satisfied a series of requirements, may in time qualify for permanent residence and work rights. ${ }^{51}$ These approaches would as a matter of necessity expedite the desired East African Co-operation, through its new East African Co-operation M inistry. Lastly, even refugee-specific legislation would not be a definite solution to this protracted situation, but would provide a benchmark within 
the national level the absence of which disables international refugee law.

If the authorities are serious in this region, they should realize that refugees could help to expand the Great Lakes economic "cake" because the region seriously needs to tap skilled labour from all angles. Thefreemovement of capital, goods, and labour would ultimately promote the prosperity of the region. This was the concern of the East African Law Society conference on the "East Africa Court of Appeal and Conflict Resolution." ${ }^{52}$ This will promote respect for human rights and refugeeism in the region and perhaps prove to governments that: "it is not only a bundle of belongings that a refugee brings to his new country." 53

\section{Notes}

1. Statement of a local Turkana man on a visit to the camp in 1998. The author does not subscribe to this perception of the refugee, but uses the statement as an analytical tool for understanding the issues surrounding the protection of refugees in Kakuma.

2. See "Refugees M ust M ove, Says State," Daily Nation, $7 \mathrm{M}$ arch 2001.

3. See "Throw out Refugees, Says MPs," Daily N ation, 16 July 2002.

4. Fieldwork in Kakuma and Dadaab refugee camp from July 2001 to September 2002 gave new insights that enabled the analysis of the extent to which the efforts to harmonize the refugee-host relation have succeeded.

5. See online: <www.refintl.org/cgi-bin/ri/bulletin?bc=00271> and <http://209.120.133.211/walking_boys.htm> (date accessed: 14 M ay 2002).

6. EDP-UNHCR SO Kakuma, StatisticsU pdateN ationality, Gender and Age Group (Present at H eadcount), 29 August 2002.

7. See Guglielmo Verdirame, "Human Rights and Refugee Camps in Kenya," J ournal of Refugee Studies 12:1 (1999).

8. See Jeff Crisp, "A State of Insecurity: The Political Economy of Violence in Kenya's Refugee Camps," African Affairs 99 (2000): 601-32.

9. Art. 1 of the 1951 Convention.

10. S. Pitterman, "Determinants of Policy in a Functional International Agency: A Comparative Study of United Nations $\mathrm{H}$ igh Commissioner for Refuges (UNHCR) Assistance in Africa, 1963-1981" (Ph.D. dissertation, N orthwestern University, Evanston, Illinois, 1984), 136.

11. Supra note 8.

12. Guy S. Goodwin-Gill, The Refugee in International Law, 2nd ed., (Oxford: Oxford University Press, 1996), 1.

13. Ibid., 3-77.

14. Ahmed Karadawi, "Constraints and Assistance to Refugees: Some Observations from the Sudan," World Development, 11:6 (1983): 539.

15. Letter to the UN HCR, "Kakuma Turkana proposed assistance from UNHCR branch office through UNHCR sub-office, Kakuma," 15 September 1997.
16. Ibid.

17. Ibid.

18. Ibid.

19. See Crisp for details of refugee violence in Kenyan camps.

20. Letter to MP, "Kakuma Youth Proposals to the Hon. M P," 10 January 1998.

21. Crisp, 619.

22. Letter to the IRC Country Representative, "IRC Program to leave Kakuma urgently," 15 N ovember 1997.

23. Interview of Turkana Elders and Chief, September 2001.

24. Supra note 22

25. See "VP to Chair Crisis Talks on Refugees," Daily Nation, 17 July 2002.

26. Supra note 23.

27. Supra note 20.

28. Ibid.

29. Seechapter 9 , The Constitution of Kenya.

30. Supra note 23.

31. See generally Robert Park, "H uman M igration and the Marginal M an," American Journal of Sociology 33:4 (1928): 881.

32. W.D. Borrie, Cultural Integration of Immigrants (Paris: UNESCO, 1959), 93-94.

33. Ibid., 87.

34. G. Germani, The Sociology of M arginality (New Brunswick: Transaction books, 1981): 92. See also J. Perlman, The M yth of M arginality (Berkeley and Los Angeles: University of California Press, 1976), 132.

35. Interview of Ethiopian and Rwandan communities, Kakuma, September 2002.

36. M. Bulcha, Flight and M igration: Causes of M ass Exodus from Ethiopia and Problems of Integration in the Sudan (The N etherlands: Uppsala, 1988), 175.

37. L. Baskauskas, "The Lithuanian Refugee Experience and Grief," International M igration Review, 15:1,2 (1981): 276-91.

38. W. S. Bernard, "Indices of integration in the American community", International M igration: Quarterly review of the intergovernmental Committee of European Migration and the Research Group for European M igration problems 11-3 (1973).

39. B. Harrell-Bond, Imposing Aid: Emergency Assistance to Refugees (Oxford: Oxford University Press, 1986).

40. Bulcha, 175.

41. The advocacy of pro-legislation groups like the ad hoc refugee advocacy group in 1997-1999, now the Refugee Consortium of Kenya (RCK).

42. See Jeff Otieno, "230,000 Face Starvation in Refugee Camps, Says UN Body," Daily Nation, 23 January 2003.

43. See D. Korn, Exodus within Borders: An Introduction to the Crisis of Internal Displacement (W ashington, D.C: Brookings Institution, 1999).

44. OCH A, Guidelines on Internal Displacement, 1999.

45. See generally A.C. Helton, The Price of Indifference: Refugees and Humanitarian Action in the New Century (New York: Oxford University Press, 2002).

46. See ICJ-Kenya Section, Protecting Refugee Rights in Kenya (Nairobi: Bookprint Services, 1998). 
47. Supra note 23.

48. Harrell-Bond, 1986.

49. Ibid.

50. P. Kuruk, "Asylum and the Non-Refoulement of Refugees: The Case of the Missing Shipload of Liberian Refugees," Stanford Journal of International Law 35(1999): 313.

51. See Human Rights Watch, "Prohibited person": Abuse of Undocumented M igrants, Asylum Seekers, and Refugees in South Africa (N ew York: Human Rights Watch, 1998).

52. M alindi, Kenya, 8-9 A pril 1998; pledging inter alia that “... the regional co-operation in E.A should seek to promote the right to development, ... the protection of fundamental rights and broaden democratic principles among member countries....and that.... therespectivegovernmentsto enact enabling statute laws to enforce international instruments of human rights protection to which they are party ...."

53. Anonymous.

Ekuru Aukot is currently completing a doctoral thesis at the University of Warwick, UK, on the following theme: "The Localization of International Refugee Law: The Implications of Law, Policy, and Practice of Refugee Admission and Protection in Kenya." His education includes an LL.B. (Nairobi), LL.M . (Warwick), and Dip. Law (Kenya School of Law). He is an Advocate of the High Court of Kenya.

(C) Ekuru Aukot, 2003. This open-access work is licensed under a Creative Commons Attribution-NonCommercial 4.0 International License, which permits use, reproduction and distribution in any mediuff for non-commercial purposes, provided the original author(s) are credited and the original publication in Refuge: Canada's Journal on Refugees is cited. 